\title{
PRODUCTION AND ECONOMIC RESULTS OF INTENSIVE CARP (Cyprinus Carpio) FARMING IN SERBIA
}

\author{
Zoran Rajić' ${ }^{1}$, Nada Vignjević-Đorđević2 ${ }^{2}$ Stevan Čanak
}

\begin{abstract}
Summary
Carp production in Serbia is traditionally conducted in large area fish farms under a semiintensive farming system. Total area under fish farms in Serbia amounts to approximately 11 thousand hectares, with 8.5 thousand hectares being under exploitation each year.

In 2004, a significant intensification of production began at fish farms in Serbia which have traditionally organized their production under a classic semi-intensive farming system. Intensification of production was undertaken with partial or complete feeding with pelleted complete feeds. That way carp production per area unit $(\mathrm{kg} / \mathrm{ha}$ ) was increased by over $50 \%$. Apart from intensification by means of using the complete extruded feeds, construction of specialized fish farms for intensive carp production started in 2003. At this moment (2016) their area amounts to several hundred hectares.
\end{abstract}

Data from intensive carp fish farms indicate that production of one- and two-year fish has been approximately 3t/ha in the period from 2003 until today, with a mild increase during the last couple of years.

With the purpose of determining the cost effectiveness of investments in fish ponds for intensive carp production two organization-economic models have been analyzed in the study. The models have been formed based on in line with the specific features of the Serbian carp farming, which has been analyzed both on the basis of data obtained from the scientific and specialist literature but also from the production practice.

Models of intensive carp production in technical and production sense have been defined in the study and production plans have been prepared. Therefore, based on such defined models,

1 Zoran Rajić Ph.D., Full Professor, University of Belgrade, Faculty of Agriculture Nemanjina street no. 6, Zemun, Serbia, Phone: +381 1144134 14, E-mail: zorajic@agrif.bg.ac.rs

2 Nada Vignjević-Đorđević Ph.D., Associate professor, State University of Novi Pazar, Department for Economic sciences, Vuka Karadžića street nn, 36300 Novi Pazar, Serbia, Phone: +381 20317752, E-mail: nvignjevic@np.ac.rs

3 Stevan Čanak Ph.D., Assistant Professor, State University of Novi Pazar, Department for Chemical-Technological sciences, Vuka Karadžića street nn, 36300 Novi Pazar, Serbia, Phone: +381 20317752, E-mail: scanak@np.ac.rs

EP 2016 (63) 4 (1445-1458) 
dynamic methods have been prepared for assessment of economic effects of the investments. The results of the analysis have demonstrated that investment in intensive carp production on 10ha fish farm is not, and on 50ha fish farm is barely economically justifiable, as well as methods for improvement of economic effectiveness.

Key words: carp ponds, economic effects, models, intensive production systems, investments

JEL: $Q 120$

\section{Introduction}

Fishery consists of farming fish in ponds (aquaculture), catching fish in open waters and fish processing. Within fishery, carp farming in Serbia occupies the most important place, both in terms of fish produced and in terms of its value.

Apart from the importance the carp fishery has within the Serbian fishery, its connection to other activities is very important. The food which is used to feed the carp and accompanying fish species originates from local production. Apart from the traditionally used grains produced at the territory of Serbia, in the last decade there has been a sudden development in production of complete compound feeds for carp feeding. The need to intensify production has been a precondition for this. Based on this need, significant production capacities for extruded feed have been constructed, its use has been expanded and even export has been initiated.

Increase in production of freshwater fish led to the beginning of a stronger development of processing activities, whereby significant processing capacities have been constructed for fish processing in line with the most up-to-date global standards.

Based on everything above, it may be said that in the last ten years we have been witnessing an accelerated development of carp fishery in Serbia with accompanying related activities.

If alignment with the European Union is taken into account, as well as the annual production on carp fish farms of cca 12 thousand tons with the concurrent development of production of feed for intensive carp farming and development of processing capacities, the level of importance this production may have within the European market may undoubtedly be observed.

Due to everything mentioned above, the importance of analysis of economic effects of construction and exploitation of the fish ponds for intensive carp farming is evident.

Sources of data and working methods

Different method procedures have been used in this study, both during the research and during the analysis and the presentation of the obtained research results.

During the economic analysis of the exploitation of different fish pond models as well as the effects of investments in carp fishery, the method of constructing organizationeconomic models has been used. After the model has been defined and all technical and 
technological characteristics of the defined model described, the following methods of economic analysis have been applied:

- Calculation based on variable costs (Direct Costing Method), which has been done for all age categories of the farmed fish within the defined models;

- Investment calculation, which has served for assessment of the cost-effectiveness of construction of certain organization-economic models of carp ponds. Economic efficiency of invested funds in certain defined models has been tested on the basis of dynamic methods of investment calculation such as the Net present value method, Internal rate of return method and Dynamic pay-back period method.

Data from several sources have been used in preparation of this study.

The first group of data consists of the data from professional literature which helped define the production plans of the selected models.

The second group of data includes the data from practice. They include production plans, fish catch balances and analyses of production from several carp ponds in Serbia within a longer period. This source of data is especially important in determining the average values over several years for the quantities of farmed fish, caught fish, losses, conversion, etc. i.e. the most important data for compiling the production plans for the defined models. These data were obtained based on semi structured oral interviews with professionals in the field.

The third group consists of data related to the area of fishery in general and to the special area of carp fishery. These data are related to research studies, construction of fish ponds, various technical parameters and problems, production technology, etc. Also, scarce in number sources and data related to costs of carp and other fish farming are included in this group.

\section{Intensive carp production in Serbia}

Production of carp and accompanying species is conducted in Serbia at around 11.5 thousand hectares (Ćirković et al., 2002; Bugarčić, 2007) where approximately 8.7 thousand hectares represent the water mirror area (Republic Statistical Office, 2015). Fish farming is conducted in semi-intensive and intensive farming systems. Carp ponds are supplied with water from different sources: canals, open waterways - rivers and from wells.

The fish ponds engaged in intensive carp production are supplied with water mainly from the wells and from the canals, while the supply of large fish ponds is conducted from rivers and the DTD canal system.

Smaller sized fish ponds have mainly been constructed during the last 20 years and production in them is in some extend undertaken according to the intensive farming system. Contrary to them, almost all large carp ponds have been built before and production is conducted in the semi-intensive farming system there. 
Considerable difference between the fish ponds where production is conducted in the semi-intensive system and those where farming is conducted in the intensive system is present in the accompanying fish species farmed alongside carp. Thus, in the intensive systems, carp is farmed as the only species - in monoculture while in the semi-intensive fish ponds it is customary to farm carp in polyculture with other fish species. There are also exceptions to the above mentioned.

The yield per hectare within the semi-intensive systems of carp farming ranges between $1,000 \mathrm{~kg} / \mathrm{ha}$ and $2,000 \mathrm{~kg} / \mathrm{ha}$, depending on whether and to what extent the extruded carp feed is used and whether the agrotechnical measures have been implemented. Similar information may also be found in works of other authors (Horvat et al., 2002). In the fish ponds for intensive farming, the production per hectare is approximately $3,000 \mathrm{~kg} / \mathrm{ha}$ which represents the average for several years (Đanić, 2010, Milošević, 2013, Čičovački, 2016).

Other information may be found about the intensive fish farming in the region (Gospić, 2009, Gyalog et al., 2011), where it may be seen that carp production under an intensive farming system in Serbia is still not at a high level.

The intensive carp farming is conducted in Serbia almost exclusively in earthen fish ponds. The Law on protection and sustainable development of the fish resources ("Official gazette RS", no. 36/2009) prohibits the placement of cages for fish farming in rivers and natural lakes.

The fish ponds for intensive carp farming differ from the fish ponds where production is conducted in a semi-intensive system in several features. The main difference is in the manner of feeding and possibility of complete control over the quality of water. Other differences are in the area of the farming pond, depth of the pond, more intensive application of the agrotechnical measures, the need for more frequent removal of the pond sludge, better technical equipment, etc. Definitions of the fish ponds for intensive carp farming and differences between them may be found with different authors (Bohl, 1999, Ćirković et al., 2002) whereby a difference must be made between the intensive and super intensive farming systems, the latter including water recirculation and its heating (Horvat et al., 2002).

Ćirković et al. $(2000,2015)$ have provided more detailed requirements for facilities for intensive carp production in Serbian conditions, where they have stressed the need to ensure additional quantities of water for re-filling and refreshing the pond facilities during the summer months.

\section{Models of intensive carp production}

Based on the previously stated and the data about the fish ponds where carp production is conducted in the intensive system in Serbia, the organization-economic models may be defined.

A fish pond for intensive carp production in Serbia is an earthen pond, filling is done 
with water and refilling during the summer is done by means of pumps while emptying is gravitational. Water from wells is used as a water source. Fish ponds are equipped with aerators for enrichment of the water with oxygen during the summer months. Construction of ponds is done on the land which has been leased from the state.

Organization-economic models have been prepared for two fish farms of different usable areas, i.e. for 10 ha and 50 ha.

Model M1. Intensive carp farming on a fish pond with usable area of 10ha

The average size of the lake is $2.5 \mathrm{ha}$, while the total usable area is 10 ha. The water depth is $2.5 \mathrm{~m}$. Aerators are used between July and September during the night. Catching is done at the end of the season, in November. A container for temporary placement for workers is foreseen at the fish pond as well as a canopy for equipment, feed, etc. $100 \mathrm{~m}$ long access road and internal transport routes in the fish pond in the length of $100 \mathrm{~m}$ should also be present. Connecting the electric energy to the facility is foreseen in the length of $100 \mathrm{~m}$. It is not necessary to obtain a power substation. Carp farming is done in monoculture, by applying pure carp culture.

Model M2. Intensive carp farming on a fish pond with usable area of 50ha

The average size of the lake is 5 ha, while the total usable area is 50 ha. The water depth is $2.5 \mathrm{~m}$. Aerators are used between July and September during the night. Catching is done at the end of the season, in November. A total of $600 \mathrm{~m}$ roads need to be constructed and electric energy connected in the length of $300 \mathrm{~m}$. Procurement of a power substation for supply of power to the fish pond is mandatory. Carp farming is done in monoculture, by applying pure carp culture.

In Table 1 the necessary investments are presented for fish ponds construction defined by M1 and M2 models.

Table 1. Necessary investments for M1. and M2.

\begin{tabular}{|c|r|r|r|r|}
\hline \multirow{2}{*}{$\begin{array}{c}\text { Monetary expenses during } \\
\text { construction of fish ponds }\end{array}$} & \multicolumn{2}{|c|}{ M1 } & \multicolumn{2}{c|}{ M2 } \\
\cline { 2 - 5 } & $\boldsymbol{€}$ & $\mathbf{\%}$ & $\boldsymbol{\epsilon}$ & \% \\
\hline Documentation (designs and licences) & 10,350 & 9.6 & 19,750 & 5.0 \\
\hline Hydro-construction facilities & 82,190 & 76.0 & 313,670 & 79.5 \\
\hline Buildings, machines and devices & 10,140 & 9.4 & 54,690 & 13.9 \\
\hline Equipment & 5,400 & 5.0 & 6,470 & 1.6 \\
\hline Total $€$ & $\mathbf{1 0 8 , 0 8 0}$ & $\mathbf{1 0 0 . 0}$ & $\mathbf{3 9 4 , 5 8 0}$ & $\mathbf{1 0 0 . 0}$ \\
\hline Total $€ / \mathrm{ha}$ & 10,808 & - & 7,892 & - \\
\hline
\end{tabular}

Source: modified according to Čanak et al., 2013.

The necessary funds for construction of fish ponds and procurement of equipment are $108,080 €$ for $M 1$, i.e. $10,808 € /$ ha and $349,580 €$, i.e. $7,892 € /$ ha for the model M2.

Carp production in monoculture according to the models M1 and M2 is conducted in a two-year plant. The production cycle starts with procurement of carp alevins and ends 
with production of a two-year old fish for consumption.

In order to prepare the production plans, the key data are related to the density of the culture, initial mass, losses and final mass, as well as the feed conversion ratio. Other indicators of successful production may be calculated on the basis of these data.

Density of the carp culture mostly depends on the age category of the progeny and the farming system. For production of one-month carp progeny $(\mathrm{Cm})$ the density of the culture should be $500,000 \mathrm{pcs} /$ ha in order to have 30 -day old progeny at between $1.5 \mathrm{~g}$ and 2.5g (Marković, 2010). Ćirković et al (2000) states that the larvae culture for production of month-olds may not be greater than $600,000 \mathrm{pcs} / \mathrm{ha}$, if the intention is to produce month-olds with average mass of $2 \mathrm{~g}$. Production of one-month carp progeny may not be, regardless of the type of additional food (grains or extruded mixtures) considered completely intensive due to the fact that the natural food (zooplankton) plays a very important role in this phase of farming.

Production of one-year carp (C1) from one-month old ones as well as production of two-year carp for consumption (C2) is conducted in such culture densities so that the natural food plays an insignificant role, while the entire yield is provided from the complete extruded feed. During farming of the one-year carp (C1) the culture density should range between $15,000 \mathrm{pcs} / \mathrm{ha}$ and $30,000 \mathrm{pcs} / \mathrm{ha}$, whereby it may be expected for the one-year progeny (C1) to have an average mass over 100g (Marković, 2010). According to other data, the culture density for production of one-year progeny should range from 20,000 pcs/ha to 30,000 pcs/ha (Milošević, 2013).

During the production of the two-year carp for consumption (C2) with mass between $1.3 \mathrm{~kg}$ and $2 \mathrm{~kg}$, it is necessary to cultivate $2,000-3,000 \mathrm{pcs} / \mathrm{ha}$ of one-year carp progeny (C1) (Milošević, 2013). Production of about 3 t/ha of both one-year and two-year carp is a characteristic example of intensive carp production in Serbia (Đanić, 2010), where it should be noted that, in the last couple of years, the average production has been slightly increasing (Čičovački, 2016).

Death rate during production of month-old fish ranges between $30 \%$ and $70 \%$ (Marković, 2010), while other authors state examples where the death rate has been $35 \%$ (Ćirković et al, 2002). During production of one-year carp, the losses range between $20 \%$ and $40 \%$ (Marković, 2010). During farming of the two-year carp one must expect losses between $20 \%$ and $40 \%$, according to the same author.

The overwintering losses represent a special category of losses and consist both of fish dying during the winter months and the weight loss of fish. This category of losses has not been sufficiently elaborated in literature, although there are important pieces of information to be found with several authors (Schäpperclaus und Lukovics, 1998). Data and experiences from certain fish farms are also of great importance.

Based on the previously mentioned data, the production plans for M1 and M2 models may be defined. 
Table 2. Production plan for the M1 model

\begin{tabular}{|c|c|c|c|c|c|c|c|c|c|c|c|}
\hline & \multicolumn{5}{|c|}{ Stocking } & \multicolumn{5}{|c|}{ Production } \\
\hline Cat & $\begin{array}{c}\text { Bк }(\mathrm{pcs} / \\
\mathrm{ha})\end{array}$ & $\begin{array}{c}\mathrm{Mp} \\
(\mathrm{g})\end{array}$ & $\begin{array}{c}\text { Mnj } \\
(\mathrm{kg})\end{array}$ & $\begin{array}{c}\mathrm{A} \\
(\mathrm{ha})\end{array}$ & $\begin{array}{c}\mathrm{Mnu} \\
(\mathrm{kg})\end{array}$ & $\begin{array}{c}\mathrm{Bku} \\
(\mathrm{pcs})\end{array}$ & $\begin{array}{c}\mathrm{U} \\
(\%)\end{array}$ & $\begin{array}{c}\text { Bkp } \\
(\mathrm{pcs})\end{array}$ & $\begin{array}{c}\mathrm{Mp} \\
(\mathrm{g})\end{array}$ & $\begin{array}{c}\mathrm{Jp}(\mathrm{kg} / \\
\mathrm{ha})\end{array}$ & $\begin{array}{c}\mathrm{Pu} \\
(\mathrm{kg})\end{array}$ \\
\hline Cm & 583,333 & - & - & 0.5 & - & 350,000 & 40 & 175,000 & 2.0 & 700 & 350 \\
\hline C1 & 23,077 & 2.0 & 46 & 2.0 & 92 & 46,154 & 35 & 30,000 & 200 & 3,000 & 6,000 \\
\hline C2 & 2,353 & 170 & 400 & 8.0 & 3,200 & 18,824 & 25 & 14,118 & 1,700 & 3,000 & 24,000 \\
\hline Total & & & & $\mathbf{1 0}$ & $\mathbf{3 , 2 9 2}$ & $\mathbf{4 1 4 , 9 7 7}$ & & $\mathbf{2 1 9 , 1 1 8}$ & & $\mathbf{3 , 0 3 5}$ & $\mathbf{3 0 , 3 5 0}$ \\
\hline
\end{tabular}

Note: $\mathrm{Cm}$ is farmed at the same facilities as $\mathrm{C} 1$

Source: author's calculation.

Stocking is conducted with appropriate progeny in densities per hectare (Bk) depending on the age category. Average mass of the stocked (Mp) fry is $2 \mathrm{~g}$ for the production of one-year carp fingerlings and $170 \mathrm{~g}$ for production of fish for consumption. Based on the previous two data, the total necessary quantity of the progeny for stocking per hectare (Mnj) may be calculated, which, multiplied by the area of the lake where a certain age category of progeny $(\mathrm{A})$ is being cultivated gives the total necessary quantity of progeny for cultivation on an entire pond (Mnu). If the total necessary number of progeny of certain age categories for stocking on an entire pond $(\mathrm{Bku})$ is reduced by death rate during farming $(\mathrm{U})$ the total number of remaining progeny is obtained (Bkp), which multiplied by the final average mass (Mp) gives the total production at the fish pond $(\mathrm{Pu})$. Data about the unit production (Jp) i.e. production of some of the carp age categories per hectare may be obtained from the data about the total production $(\mathrm{Pu})$ by dividing it with the area on which a certain age category has been cultivated.

Data about the total production is related to the quantity of the caught progeny at the end of the farming season i.e. in November and December. Due to overwintering losses, this quantity shall not be equal to the quantity which may be sold and it is necessary to take these losses into account as well. In Table 3, the overwintering losses are presented for the M1 model.

Table 3. Overwintering losses for the M1 model

\begin{tabular}{|c|c|c|c|c|c|c|c|}
\hline & \multicolumn{2}{|c|}{$\begin{array}{c}\text { Overwintering } \\
\text { losses }\end{array}$} & \multicolumn{5}{|c|}{ Fish after overwintering } \\
\hline Categ. & $\mathrm{Kz}(\%)$ & $\mathrm{Un}(\%)$ & $\mathrm{Bk}(\mathrm{pcs})$ & $\mathrm{Mp}(\mathrm{g})$ & $\mathrm{Um}(\mathrm{kg})$ & $\mathrm{Bz}(\mathrm{pcs})$ & $\mathrm{S}(\mathrm{kg})$ \\
\hline Cm & 0 & 0 & 175,000 & 2.0 & 350 & 46,154 & 258 \\
\hline C1 & 15 & 3 & 29,100 & 170 & 4,947 & 18,824 & 1,747 \\
\hline C2 & 5 & 1 & 13,976 & 1,615 & 22,572 & - & 22,572 \\
\hline Total & - & - & $\mathbf{4 3 , 0 7 6}$ & - & $\mathbf{2 7 , 5 1 9}$ & - & $\mathbf{2 4 , 5 7 7}$ \\
\hline
\end{tabular}

Source: author's calculation

Overwintering losses consist of overwintering weight loss $(\mathrm{Kz})$, which represents the loss in the mass of surviving specimens and fish death rate during overwintering (Un). Based on these data, the surviving number of pieces is obtained after overwintering 
(Bk) and average fish mass after overwintering (Mp). One month-old carp fry $(\mathrm{Cm})$ does not go in overwintering but is used for production of one-year carp fingerlings, while some time is necessary for sale of fish for consumption (C2) where smaller losses may occur. The quantity of fish which is at disposal at the end of overwintering is in the column designated with Um and this quantity shall serve to calculate the production value. One part out of that quantity shall be used for direct sale (S) and another one for cultivation in own pond $(\mathrm{Bz}=\mathrm{Bku})$.

The production plan for the M2 model is very similar to the M1 model production plan, the difference being that production of one-month progeny is conducted at an area of 1 ha, production of one-year progeny at 7 ha and production of fish for consumption at 43ha, thus the quantities of the produced different age carp categories $(\mathrm{Cm}, \mathrm{C} 1$ and $\mathrm{C} 2)$ are proportionally higher.

Calculations have been made on the basis of variable costs for the M1 and M2 models, by means of production plans.

Table 4. Calculation on the basis of variable costs for the M1 model.

\begin{tabular}{|c|c|c|c|c|c|c|c|c|c|c|c|c|}
\hline & \multicolumn{4}{|c|}{$\mathrm{Cm}$} & \multicolumn{4}{|c|}{$\mathrm{C} 1$} & \multicolumn{4}{|c|}{$\mathrm{C} 2$} \\
\hline & Qty & Unit & $\begin{array}{c}\text { Price } \\
(€)\end{array}$ & $\begin{array}{l}\text { Value } \\
(€)\end{array}$ & Qty & Unit & $\begin{array}{c}\text { Price } \\
(€)\end{array}$ & $\begin{array}{l}\text { Value } \\
(€)\end{array}$ & Qty & Unit & $\begin{array}{c}\text { Price } \\
(€)\end{array}$ & $\begin{array}{l}\text { Value } \\
(€)\end{array}$ \\
\hline $\begin{array}{c}\text { Value of } \\
\text { production ( }(\mathrm{E} / \mathrm{ha})\end{array}$ & 700 & kg & 6,6 & 4.620 & 2.474 & kg & 2,86 & 7.074 & 2.822 & kg & 2,20 & 6.207 \\
\hline Area surface (ha) & 0,5 & ha & - & - & 2,0 & ha & - & - & 8 & ha & - & - \\
\hline $\begin{array}{c}\text { Variable costs } \\
(€ / \mathrm{ha})\end{array}$ & & & & & & & & & & & & \\
\hline Stocking & 700.000 & $\begin{array}{c}1000 \\
\text { pcs }\end{array}$ & 100 & 700 & 46 & $\mathrm{~kg}$ & 6,6 & 305 & 396 & $\mathrm{~kg}$ & 2,86 & 1.133 \\
\hline Feed & 840 & $\mathrm{~kg}$ & 0,9 & 756 & 4,431 & $\mathrm{~kg}$ & 0,6 & 2.658 & 4.420 & $\mathrm{~kg}$ & 1 & 2.652 \\
\hline Compost & 3 & $\mathrm{t}$ & 20 & 60 & 0 & $\mathrm{t}$ & 20 & - & 0 & $\mathrm{t}$ & 20 & - \\
\hline Lime & 500 & $\mathrm{~kg}$ & 0,06 & 30 & 1000 & $\mathrm{~kg}$ & 0,06 & 60 & 1000 & $\mathrm{~kg}$ & 0,06 & 60 \\
\hline $\begin{array}{l}\text { Medicine, } \\
\text { chemicals }\end{array}$ & $\begin{array}{l}\text { theo- } \\
\text { retical }\end{array}$ & $€$ & - & 50 & $\begin{array}{l}\text { theo- } \\
\text { retical }\end{array}$ & $€$ & - & 100 & $\begin{array}{l}\text { theo- } \\
\text { retical }\end{array}$ & $€$ & - & 100 \\
\hline Var. mach. costs & $*$ & $€$ & - & 202 & $*$ & $€$ & - & 606 & $*$ & $€$ & - & 808 \\
\hline $\begin{array}{l}\text { Working variable } \\
\text { costs }\end{array}$ & $*$ & $€$ & - & 87 & $*$ & $€$ & - & 203 & $*$ & $€$ & - & 290 \\
\hline Electricity VT & $*$ & $€$ & - & 114 & $*$ & $€$ & - & 194 & $*$ & $€$ & - & 194 \\
\hline Vet fees & 0 & $\%$ & - & - & 0 & $\%$ & - & - & 0.2 & $\%$ & - & 12,41 \\
\hline $\begin{array}{c}\text { Summary VC } \\
(€ / \mathrm{ha})\end{array}$ & & & & 1.999 & & & & 4.126 & & & & 5.249 \\
\hline $\begin{array}{c}\text { Contribution } \\
\text { margin } \mathrm{CM}(€) \\
\text { ha) }\end{array}$ & & & & 2.621 & & & & 2.948 & & & & 958 \\
\hline Summary CM $(€)$ & & & & 1.310 & & & & 5.896 & & & & 7.664 \\
\hline
\end{tabular}

Source: author's calculation 
Pursuant to calculations on the basis of variable costs, the values of contribution margins for production of different carp age categories have been obtained, which enables the total contribution margin for the model as a whole to be obtained. The quantities of unit production per hectare after overwintering $(\mathrm{Bz})$ are the same for both models, M1 and M2 and thus the values of production per hectare shall be equal. Difference in the value of production between the M1 and M2 models originates from different pond areas. Variable costs, on the other hand, differ due to different costs of manpower, electric power and variable machine costs, so the contribution margins for different age categories of progeny $(\mathrm{Cm}, \mathrm{C} 1$ and $\mathrm{C} 2)$ shall be different. Data for variable costs of manpower and variable portion of the costs of electric power are calculated in separate tables.

Data about the value of production, variable costs and contribution margin for models M1 and M2 are presented in Table 5, both for fish ponds as a whole, and per carp age categories.

Table 5. Contribution margins for M1 and M2 models

\begin{tabular}{|c|c|c|c|c|c|}
\hline & $\begin{array}{c}\text { Fish } \\
\text { category }\end{array}$ & $\begin{array}{c}\text { Production } \\
\text { value } \\
\text { (€/ha) }\end{array}$ & $\begin{array}{c}\text { Variable costs } \\
\text { VB } \\
(€ / h a)\end{array}$ & $\begin{array}{c}\text { Contribution } \\
\text { margin CM (€) } \\
\text { ha) }\end{array}$ & $\begin{array}{c}\text { Summary } \\
\text { CM } \\
(€) \\
\end{array}$ \\
\hline \multirow{4}{*}{ Model M1 } & $\mathrm{Cm}$ & 4,620 & 1,999 & 2,621 & 1,310 \\
\hline & $\mathrm{C} 1$ & 7,074 & 4,126 & 2,948 & 5,896 \\
\hline & $\mathrm{C} 2$ & 6,207 & 5,249 & 958 & 7,664 \\
\hline & \multicolumn{4}{|c|}{ CM Total (€) } & 14,870 \\
\hline \multirow{4}{*}{ Model M2 } & $\mathrm{Cm}$ & 4,620 & 1,961 & 2,659 & 2,659 \\
\hline & $\mathrm{C} 1$ & 7,076 & 4,199 & 2,877 & 20,137 \\
\hline & $\mathrm{C} 2$ & 6,207 & 5,061 & 1,146 & 49,272 \\
\hline & \multicolumn{4}{|c|}{ CM Total (€) } & 72,068 \\
\hline
\end{tabular}

Source: author's calculation

The total contribution margin for the M1 model is $14,870 €$ and for the M2 model it is $72,068 €$. Based on these data and data about other monetary expenses for acquiring an investment facility, i.e. construction of the fish pond for intensive carp farming, as defined in M1and M2 models, an investment calculation may be prepared in order to calculate the annual yield from an investment.

Table 6. Investment calculation

\begin{tabular}{|l|c|c|}
\hline Elements / Models & M1 (€) & M2 (€) \\
\hline Initial investment & $\mathbf{1 0 8 , 0 8 0}$ & $\mathbf{3 9 4 , 5 8 0}$ \\
\hline Production value & 66,117 & 321,063 \\
\hline Variable costs & 51,247 & 248,995 \\
\hline Contribution margin & $\mathbf{1 4 , 8 7 0}$ & $\mathbf{7 2 , 0 6 8}$ \\
\hline Land lease & 275 & 1,375 \\
\hline Water allowance & 683 & 3,414 \\
\hline Operating costs & 4,940 & 27,988 \\
\hline Property tax & 329 & 1,255 \\
\hline
\end{tabular}




\begin{tabular}{|l|c|c|}
\hline Electricity & 500 & 1,000 \\
\hline Fuel & 1,320 & 1,760 \\
\hline Maintenance & 1,249 & 5,896 \\
\hline Annual allowance for inv. & 60,543 & 291,683 \\
\hline Annual investment yield & $\mathbf{5 , 5 7 4}$ & $\mathbf{2 9 , 3 8 1}$ \\
\hline Liquidation value & $\mathbf{6 5 , 7 5 2}$ & $\mathbf{2 5 0 , 9 3 6}$ \\
\hline
\end{tabular}

Source: Modified acc. to Čanak, 2012

The value of carp production after overwintering is the annual investment yield, whether the fish has been sold or used for own culture. Apart from variable costs, lease of the land for construction of fish pond, allowance for water consumption (Regulation on the fees for water in 2015, 2015), operating costs for full time employees, property tax (The Law on Property Taxes, 2001, 2002, 2004, 2007, 2009, 2010), electricity allowances which do not have variable character, allowances for fuel, as well as maintenance of pond facilities, construction facilities, other capital assets and equipment are included in the category of annual investment allowances. Liquidation value of an investment facility has been estimated at $80 \%$ of the initial value.

With the aid of previously calculated indicators from investment calculation for sole annual investment yield, initial investment for construction of a pond and procurement of the necessary equipment the indicators of cost effectiveness of investments may be calculated by previously known dynamic methods (Andrić et al, 2005). A period of 20 years is adopted as an investment term while the rate of $4 \%$ has been used for the calculating interest rate. The same moment is used for calculation of economic effectiveness indicators and for the moment of calculation, that being the moment immediately prior to first investments.

\section{Results and discussion}

Based on the calculated data from the investment calculation (Table 6.) the calculation of all dynamic indicators of cost effectiveness of construction and exploitation of carp ponds for intensive farming has been conducted. In Table 7 dynamic economic indicators for M1 and M2 models may be seen.

Table 7. Investment cost effectiveness indicators of the M1 and M2 models

\begin{tabular}{|l|c|c|}
\hline Indicators/models & M1 & M2 \\
\hline Net present value & $-2,317 €$ & $119,235 €$ \\
\hline Internal rate of return & $3.82 \%$ & $6.51 \%$ \\
\hline Dynamic pay-back period & after $20 \mathrm{yrs}$. & at year 20 \\
\hline
\end{tabular}

Source: author's calculation

Indicator the net present value of intensive carp production investment at 10 ha (M1) has a negative value, which means that the investment defined by this model is not economically justified. Internal rate of return is smaller than the calculative interest rate 
and stands at $3.82 \%$, while the dynamic pay-back period is after a period of 20 years.

In the case of construction of a pond for intensive carp farming at 50 ha (model M2) the indicators prove economic justifiability. Net present value is $119,235 €$, upon internal rate of return at the rate of $6.51 \%$. Dynamic pay-back period is in the 20 th year of the investment term. It should be stressed that the economic justifiability of an investment does not depend on the liquidation value of the investment facility in the 20th year but that, during making a decision on potential investments, negative scenarios should be additionally considered where a decrease of annual benefit from investment may occur and investment may turn to the zone where they are not economically justified.

Even though the intensive carp production model at 50 ha (M2) shows its economic justifiability, based on the dynamic indicators of economic efficiency it may be observed that the investment defined by this model is very close to the limit where it is not economically justified. That is why a possibility of improvement of economic indicators should be considered for both models. That may practically be achieved by increase of the annual investment yield, whether by increase of annual investment yield (production value) or by decrease of the annual investment allowances.

The easiest way to increase the production value in practice is sale of portion of the produced fish for consumption at retail prices and greater presence of progeny in the production structure, so these two scenarios have been additionally reviewed.

If within the M1 model $25 \%$ of fish for consumption $(5,643 \mathrm{~kg})$ is sold at retail price of $3 € / \mathrm{kg}$ (to unions for example), the annual yield from investment shall be increased to $10,080 €$ whereby the net present value has the value of $58,912 €$ with internal rate of return of $8.52 \%$ and dynamic pay-back period in the 15 th year, thus making the investment economically justifiable.

Within the M2 model it is not realistic to assume that sale of $25 \%$ fish for consumption at retail price is possible so we assume the sale of $10 \%$ of fish for consumption at those prices. With sale of $10 \%$ of fish for consumption $(12,132.5 \mathrm{~kg})$ at retail price of $3 € /$ $\mathrm{kg}$ it is possible to increase the annual investment yield to $39,267 €$, whereby the net present value of the investment of $250,878 €$ is obtained, with internal rate of return of $9.21 \%$ and the dynamic pay-back period moved to the 14 th year.

If the production structure is changed at a fish farm with an area of 10 ha (M1) and oneyear fingerlings (C1) are produced at 4ha and fish for consumption (C2) at 6 ha, there is an increase in the annual investment yield to $9,554 €$ whereby the net present value of the investment is $51,769 €$, with internal rate of return of $7.98 \%$ and the dynamic payback period of investment is in the 16 th year of the investment term.

In case the same decision is made on the M2 model, and 12 ha is cultivated for production of one-year fingerlings (C1) and the remaining 38 ha are used for production of fish for consumption (C2), there is an increase in net present value of the investment at 353,961 $€$, with internal rate of return of $11.27 \%$ and the dynamic pay-back period of investment is in the 11 th year.

EP 2016 (63) 4 (1445-1458) 
It must be noted that one should decide to increase the production of one-year progeny only in case it may be sold. Also, it is realistic to assume that certain quantity of fish for consumption may be sold at retail price to restaurants, unions and at market places.

\section{Conclusion}

In order to estimate the economic effects of construction of fish ponds for intensive carp farming in Serbia, two organizational-economic models have been prepared and defined in terms of construction and production. Models differ in the usable area of fish ponds (10 ha and $50 \mathrm{ha}$ ), as well as in a range of other characteristics (choice of pumps, necessary power, work force, etc.). Cost effectiveness has been tested in such defined models by means of dynamic methods for assessment of economic effectiveness of investments.

Economic analysis has demonstrated that investment in an intensive carp production model on a pond with an area of 10 ha (M1) is not economically justifiable, while in the case of a pond with an area of 50 ha is economically justifiable, but close to the point of not being economically justifiable.

The possibilities for improvement of economic efficiency of investments have been considered and demonstrated that it is possible to improve considerably the dynamic economic indicators if the production structure is changed by greater presence of oneyear fingerlings and if portion of the fish for consumption is sold at retail prices.

\section{Literature}

1. Andrić, J., Vasiljević, Z., Sredojević, Z. (2005): Investicije-osnove planiranja $i$ analize. Univerzitet u Beogradu. Poljoprivredni fakultet. Beograd.

2. Bohl, M. (1998): Zucht und Produktion von Suesswasserfischen. DLG-Verlag. Muenchen.

3. Bugarčić, P. (2007): Geografske karakteristike i funkcije veštačkih jezera Vojvodine. Novi Sad. Prirodno matematički fakultet. Departman za geografiju, turizam i hotelijerstvo.

4. Čanak, S. (2012): Economic effects of establishment and exploitation of the carp fishponds in Serbia. Doctoral dissertation, unpublished. Agricultural faculty University of Balgrade.

5. Čanak, S., Vasiljević, Z., Radivojević, D., Ivanović, S., Marković, T. (2013): Influence of the carp pond model on the amount if investments for its construction. The First International Symposium on Agricultural Engineering, $4^{\text {th }}-6^{\text {th }}$ October 2013, Belgrade - Zemun, Serbia. Pages 2/20-2/33.

6. Čičovački, S. (2016): Data's from the fish farm, Somborski ribnjak”, collected in Interview.

7. Ćirković, M., Jeremić, S., Ćirković, D. (2000): Intensive farming of carp fish species. Contemporary fishery of Yugoslavia.Monograph. $4^{\text {th }}$ Yugoslav 
symposium "Fishery in Yugoslavia". Vršac, Page 56.

8. Ćirković, M., Jovanović, B., Maletin, S. (2002): Ribarstvo, biologija, tehnologija, ekologija, ekonomija. Udžbenik. Novi Sad.

9. Ćirković, M., Ljubojević, D., Novakov, N., Đorđević, V. (2015): Gajenje $i$ kvalitet mesa šaranskih riba. Monografija. Novi Sad: Naučni institut za veterinarstvo.

10. Đanić, Ž. (2010): Data 's from the carp farm „Đanič”, collected in interview.

11. Gospić, D. (2009): Intensive common carp farming based on practical experiences of G20, Slovenian fish farm. IV International conference ,Fishery”. Institute of animal science, Faculty of agriculture, University of Belgrade. 2729.5. 2009. Pages 170-174.

12. Gyalog, G., Váradi, L., Gál, D. (2011): Is intensification a viable way for pond culture in Central and Eastern Europe? AACL Bioflux4(5):584-589.

13. Horvath, L., Tamas, G. and Seagrave, C. (2002): Carp and pond fish culture. Second edition. Fishing News Books, a division of Blackwell Science Ltd. 1992, 2002. Page 163.

14. Horvath, L., Tamas, G. and Seagrave, C. (2002): Carp and pond fish culture. Second edition. Fishing News Books, a division of Blackwell Science Ltd. 1992, 2002. Pages 13-15.

15. Marković, Z. (2010): Šaran - gajenje u ribnjacima i kaveznim sistemima. Beograd. Izdanje prof. Dr. Zoran Marković.

16. Milošević, M. (2013): Datas from the fish farm „Somborski ribnjak”, collected in Interview.

17. “Official Gazette of RS“, No. 36/2009.

18. Regulation on the fees for water in 2015: „Official Gazette of RS”, No. 15/2015.

19. Republic Statistical Office- RZS (2015): Interni podaci dobijeni na osnovu zahteva autora.

20. Schäperclauss, W., Lukovics, M. (1998): Lehrbuch der Teichwirtschaft. Auflage: 4. Neubearbeitet. Berlin. Ulmer. Seite 554.

21. The Law on Property Taxes. „Official Gazette of RS”, No. 26/01, 45/02-CYC, 80/02, 135/04, 61/07, 5/09 and 101/10). 


\title{
PROIZVODNI I EKONOMSKI REZULTATI INTENZIVNE PROIZVODNJE ŠARANA (Cyprinus Carpio) U SRBIJI
}

\author{
Zoran Rajičc, Nada Vignjević-円orđevićc ${ }^{5}$,Stevan Čanak ${ }^{6}$
}

\begin{abstract}
Apstrakt
Proizvodnja šarana se u Srbiji tradicionalno sprovodi na ribnjacima velikih površina $u$ poluintenzivnom sistemu uzgoja. Ukupne površine pod šaranskim ribnjacima u Srbiji iznose oko 11 hiljada hektara, pri čemu je oko 8.5 hiljada hektara godišnje u eksploataciji.

U toku 2004 godine počinje intenzifikacija proizvodnje na šaranskim ribnjacima u Srbiji koji su tradicionalno obavljali proizvodnju u poluintenzivnom sistemu. Intenzifikacija je sprovedena uz delimičnu ili potpunu ishranu kompletnim peletiranim hranama. Na taj način proizvodnja po jedinici površine je povećana preko 50\%. Sa druge strane, nevezano od intenzifikacije proizvodnje korišćenjem kompletnih hraniva, od 2003 godine počinje izgradnja specijalizovanih ribnjaka za intenzivnu proizvodnju šarana. U ovom momentu (2016) površine intenzivnih šaranskih ribnjaka iznose nekoliko stotina hektara.

Proizvodnja na intenzivnim šaranskim ribnjacima u Srbiji iznosi oko 3t/ha, posmatrano u periodu od 2003 godine do danas, sa manjim povećanjem u poslednjih nekoliko godina.

U svrhu utvrđivanja ekonomskih efekata investiranja u ribnjake za intenzivnu proizvodnju šarana, analizirana su dva organizaciono-ekonomska modela u ovom istraživanju. Modeli su definisani u skladu sa specifičnostima uzgoja šarana u Srbiji, koji su analizirani na osnovu podataka iz naučne i stručne literature, kao i prakse.

Modeli intenzivne proizvodnje šarana su definisani u tehničkom i tehnološkom smislu, nakon čega su sastavljeni planovi proizvodnje. Nakon toga, na osnovu definisanih modela sastavljene su investicione kalkulacije pomoću kojih su obračunati dinamicki pokazatelji efektivnosti investicija. Rezultati analize su pokazali da investicija u intenzivnu proizvodnju šarana na 10ha nije opravdana, dokje investicija u intenzivnu proizvodnju na 50ha opravdana. Takođe su dodatno ispitane mogućnosti za poboljšanje ekonomske efektivnosti obe investicije.
\end{abstract}

Ključne reči: šaranski ribnjaci, ekonomski efekti, modeli, intenzivni sistemi proizvodnje, investicije.

4 Redovni profesor, dr Zoran Rajić, Univerzitet u Beogradu, Poljoprivredni fakultet, Nemanjina ulica br. 6, Zemun, Beograd, Srbija, Telefon: +381 1144134 14, E-mail: zorajic@agrif.bg.ac.rs

5 Vanredni profesor, dr Nada Vignjević-Đorđević, Državni univerzitet u Novom Pazaru, Departman za ekonomske nauke, Ulica Vuka Karadžića bb, 36300 Novi Pazar, Srbija, Telefon: +381 20317 752, E-mail: nvignjevic@np.ac.rs

6 Docent, dr Stevan Čanak, Državni univerzitet u Novom Pazaru, Departman za hemijskotehnološke nauke, Ulica Vuka Karadžića bb, 36300 Novi Pazar, Srbija, Telefon: +381 20 317 752, E-mail: $\underline{\text { scanak@np.ac.rs }}$ 